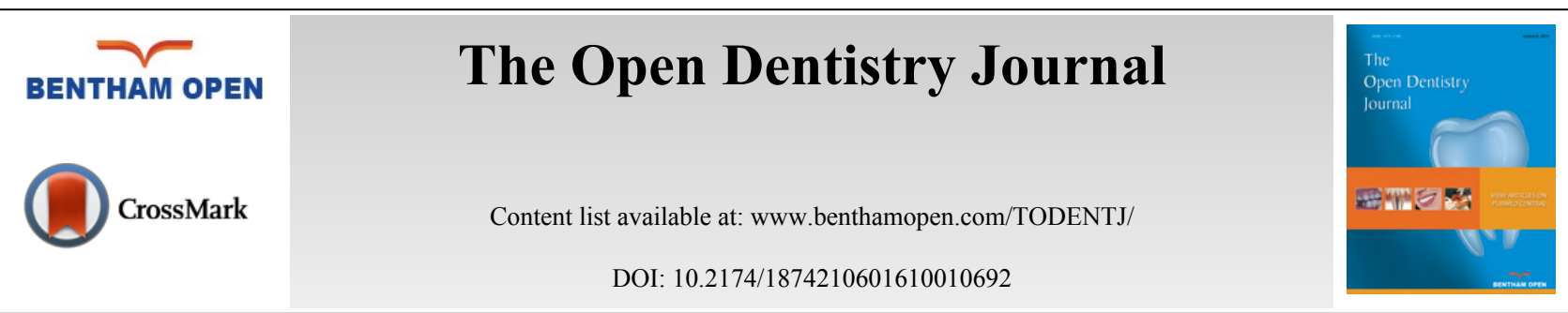

REVIEW ARTICLE

\title{
Root Canal Irrigation: Chemical Agents and Plant Extracts Against Enterococcus faecalis
}

\author{
Letizia Borzini, Roberta Condò, Paolo De Dominicis, Adriano Casaglia* and Loredana Cerroni \\ Department of Clinical Science and Translational Medicine, University of Rome "Tor Vergata", Rome, Italy
}

Received: April 18, 2016

Revised: October 12, 2016

Accepted: November 02, 2016

\begin{abstract}
:
Background:

There are various microorganisms related to intra and extra-radicular infections and many of these are involved in persistent infections. Bacterial elimination from the root canal is achieved by means of the mechanical action of instruments and irrigation as well as the antibacterial effects of the irrigating solutions. Enterococcus faecalis can frequently be isolated from root canals in cases of failed root canal treatments. Antimicrobial agents have often been developed and optimized for their activity against endodontic bacteria. An ideal root canal irrigant should be biocompatible, because of its close contact with the periodontal tissues during endodontic treatment. Sodium hypoclorite $(\mathrm{NaOCl})$ is one of the most widely recommended and used endodontic irrigants but it is highly toxic to periapical tissues.
\end{abstract}

\section{Objectives:}

To analyze the literature on the chemotherapeutic agent and plant extracts studied as root canal irrigants. In particularly, the study is focused on their effect on Enterococcus faecalis.

\section{Method:}

Literature search was performed electronically in PubMed (PubMed Central, MEDLINE) for articles published in English from 1982 to April 2015. The searched keywords were "endodontic irrigants" and "Enterococcus faecalis" and "essential oil" and "plant extracts".

Results:

Many of the studied chemotherapeutic agents and plant extracts have shown promising results in vitro.

\section{Conclusion:}

Some of the considered phytotherapic substances, could be a potential alternative to $\mathrm{NaOCl}$ for the biomechanical treatment of the endodontic space.

Keywords: Root canal irrigation, Phytotherapic substances, Enterococcus faecalis, Essential oil, Plant extracts.

\section{INTRODUCTION}

In most cases where endodontic treatments prove unsuccessful, it is due to treatment procedures that have failed to meet a satisfactory standard for control and elimination of infection [1].

The need for retreatment may be attributed to either reinfection by oral bacteria or, more often, to the persistence and regrowth of microorganisms that were not eliminated during the previous treatment. Elimination of microbes from

* Address correspondence to this author at the Department of Clinical Science and Translational Medicine, University of Rome "Tor Vergata", Rome, Italy; Tel: +39672596377; Fax: +39672596378; E-mail: a.casaglia@tiscali.it 
the pulpal tissue as well as in root canals is the main goal when aiming to prevent and treat pulpal and periapical lesions. Successful root canal therapy relies on the combination of proper instrumentation, disinfection and obturation of root canal [2].

Employment of mechanical instrumentation is the core method for bacterial reduction in the infected root canal, but achieving bacteria-free root canals still proves to be a difficult task [3].

Various studies have demonstrated that mechanical preparation with hand instruments and irrigation with saline cannot predictably eliminate the bacteria from the infected root canals [4, 5].

Therefore, the current focus of interest has been the use of irrigating solutions with strong antibacterial activity as the necessary supplement to mechanical preparation.

Nowadays, most studies focus on the antimicrobial properties of the irrigating solutions, involving both forms of bacterial growth, planktonic and biofilm. However, few studies look into the residual antibacterial activity and its influence on microbial adhesion to the dentin surface [6].

This is a relevant aspect to take into consideration because microbial adherence to the dentin is the first step in colonization, including tubule invasion, and the origin of biofilm infections.

The purpose of this paper is to give a succinct literature review of different commercially available root canal irrigants, with particular attention to their effect against E. faecalis, and the state-of-the-art irrigating solutions using plant extracts.

\section{MATERIALS AND METHODS}

The first criteria for research in PubMed/Medline were dental journals from 1982 to 2015. A first research attempt was made with the keywords "endodontic irrigants" and "Enterococcus faecalis" and it resulted in 163 articles; the second search was done with the keywords "plant extracts" and "Enterococcus faecalis" and/or "endodontic", resulting in 15-25 articles; the third search, with the keywords "Enterococcus faecalis" and "essential oil", resulted in 104 articles. Inclusion criteria: in vitro studies, antibacterial activity against $E$. faecalis, antibacterial activity of the plant extracts compared to $\mathrm{NaOCl}$ and/or Chlorhexidine, essential oil tested as an endodontic irrigant and/or present in more than two publications.

\section{Endodontic Bacteria}

Once the root canal is infected coronally, the infection progresses apically until bacterial products or bacteria themselves are in a position to stimulate the periapical tissues, thereby leading to apical periodontitis. The microorganisms and their products (endotoxins) are closely related to the etiology of pulpal and periapical lesions. They can cause pulp necrosis due to their persistence in the root canal system after endodontic treatment and can induce a periapical inflammatory reaction. Root canals with primary infections contain a high bacterial load, but chemomechanical root canal preparation has proven able to reduce bacterial counts by at least 95\% [7].

Endodontic infections have a polymicrobial nature, with obligate anaerobic bacteria conspicuously dominating the microbiota in primary infections. The root canal microbiota includes more than 700 different bacterial species some of which have not yet been identified at species level [8]. In addition to bacteria, other microorganisms like yeasts can be found in root canals with pulp necrosis [9].

The main microorganisms that are isolated before a root canal treatment include Gram-negative anaerobic rods, Gram-positive anaerobic cocci, Gram-positive anaerobic and facultative rods, (saccharolytic species such as many types of Prevotella and asaccarololytic species such as Porphyromonas, furthermore Tannerella forsythia, Dialister, Fusobacterium, Spirochetes), Lactobacillus species, and Gram-positive facultative Streptococcus [10].

Obligate anaerobes are generally eradicated by the endodontic treatment; on the contrary, facultative bacteria such as non-mutants Streptococci, Enterococci, and Lactobacilli are able to survive chemo-mechanical instrumentation and root canal irrigation [6].

\section{Enterococcus faecalis}

A commonly isolated species from persistent apical periodontitis [11 - 15], Enterococcus faecalis is a microorganism that can tolerate extreme conditions [16]. 
Its long-term survival in the root canal system could be a result of its ability to adhere to dentin and invade dentinal tubules $[17,18]$ and to form communities organized in biofilms, which may contribute to bacterial resistance and persistence after intracanal antimicrobial procedures [19].

Pinheiro et al. found E. faecalis in $52.94 \%$ of canals with bacterial growth [20]. This microorganism has demonstrated the capacity to survive in an environment in which there are available nutrients and in which commensality with other bacteria is minimal [21].

It is therefore probable that bacteria within dentinal tubules surviving chemo-mechanical instrumentation and intracanal medication may colonize the tubules and reinfect the obturated root canal [22].

Its pathogenicity ranges from life-threatening diseases in compromised individuals, to less severe conditions, such as infection of obturated root canals with chronic apical periodontitis. In the latter situation, the infecting organisms are partly shielded from the defense mechanisms of the body. The most-cited virulence factors of E. faecalis that may be related to endodontic infection and the peri-radicular inflammatory response are aggregation substance, surface adhesions, sex pheromones, lipoteichoic acid, extracellular superoxide production, the lytic enzymes gelatinase and hyaluronidase, and the toxin cytolysin. Each of them may be associated with various stages of an endodontic infection as well as with periapical inflammation. While some products of the bacterium may be directly linked to damage of the periradicular tissues, a large part of the tissue damage is probably mediated by the host response to the bacterium and its products [23].

The ability of E. faecalis to tolerate or adapt to harsh environmental conditions may act as an advantage over other species. It may explain its survival in root canal infections, where nutrients are scarce and there are limited means of escape from root canal medicaments.

In in vitro studies, E. faecalis has been shown to invade dentinal tubules [16, 24 - 26] whereas not all bacteria have this ability [24]. In animal studies, where pure cultures of various bacteria were inoculated separately into root canals, E. faecalis, unlike others, was found to colonize the root canal in most cases and to survive without the support of other bacteria $[27,28]$.

\section{Root Canal Irrigants}

Using root canal irrigant solutions has proved to be essential in endodontic treatment as they aid in disinfecting and lubricating the root canal, flushing out debris from the canal system, and dissolving organic and inorganic tissues [29].

To effectively clean and disinfect the root canal system, an irrigant should ideally: (a) have a broad antimicrobial spectrum and high efficacy, (b) be able to digest proteins and necrotic tissue, (c) prevent the formation of a smear layer during instrumentation or dissolve the latter once it has formed, (d) present low surface tension to reach areas inaccessible to the tools (dentin tubules), (e) offer long-term antibacterial effect, (f) keep dentinal debris in suspension, (g) provide a lubricating action for root canal instruments, (h) be non-antigenic, non-toxic and non-carcinogenic. In addition, it should have no adverse effects on dentin or the sealing ability of filling materials. Furthermore, it should be relatively inexpensive, convenient to apply and cause no tooth discoloration $[30,31]$.

\section{Sodium Hypochlorite}

Sodium hypochlorite $(\mathrm{NaOCl})$ is one of the most widely recommended and used endodontic irrigants for its antibacterial action and its capacity to dissolve organic tissues, and it has been so for more than 70 years [18]. Concentrations ranging from $0.5-6 \%$ have been reported in literature, with higher concentrations having better antibacterial efficacy on Enterococcus faecalis [32 - 34] but also presenting higher toxicity [35 - 37]. Giardino et al. evaluated the efficacy of $5.25 \% \mathrm{NaOCl}$ and MTAD (mixture of doxycycline, citric acid, and a detergent-Tween 80 ) and found that only $5.25 \% \mathrm{NaOCl}$ can successfully disgregate and remove the E. faecalis biofilm [38]. The latter proved more resistant to the irrigant when comprised of starved cells as opposed to stationary cells, with the efficacy of the $5.25 \% \mathrm{NaOCl}$ decreasing as the biofilm matured.

The irrigation protocol based on the alternating use of $\mathrm{NaOCl}$ and EDTA seems to promote the elimination of root canal E.faecalis biofilms [39].

However, the optimal organic tissue-dissolving property of $\mathrm{NaOCl}$ is non selective, which means that, especially at high concentrations, this chemical agent may dissolve both vital and necrotic pulp remnants indistinguishably and be toxic to periapical tissues in case of extrusion through the apical foramen to the peri-radicular space [40]. Cytotoxic and 
genotoxic effects on human peripheral lymphocytes have in fact been observed in connection with the application of sodium hypochlorite [41]. The allergic potential of $\mathrm{NaOCl}$ has already been analyzed in medical literature, but only a few cases of known hypersensitivity have been reported in dental literature [42 - 44]. Another disadvantage of $\mathrm{NaOCl}$ is that it decreases the mechanical resistance of dentin $[45,46]$ by causing deterioration of collagen and proteoglycans [47].

\section{Chlorhexidine}

Chlorhexidine is used extensively in periodontal therapy because of its substantivity and antimicrobial effects against Gram-positive and Gram-negative organisms. For these same reasons, it is also used as a root canal irrigant and intracanal medication in endodontics. It is a relatively non-toxic, broad spectrum antimicrobial agent that offers residual action with less potential for adverse effects, thus offering a clinical advantage over sodium hypochlorite. Another benefit of choosing Chlorhexidine over $\mathrm{NaOCl}$, is that the former could be used to treat patients who are hypersensitive to the latter. In fact, no adverse effects regarding the use of $\mathrm{CHX}$ as an irrigant or intracanal medicament have yet been published [48].

Delany et al. evaluated the $0.2 \%$ Chlorhexidine gluconate on infected root canals of extracted necrotic teeth [49]. Bacteriologic samples were obtained before, during, immediately after and 24 hours after instrumentation, irrigation, and medication either with Chlorhexidine gluconate or with sterile saline. There was a highly significant reduction in microorganisms in the Chlorhexidine-treated specimens after the instrumentation and irrigation procedures. Jeansonne e and White comparing 2\% Chlorhexidine and $5.25 \% \mathrm{NaOCl}$ in vitro, showed that Chlorhexidine was more effective in reducing the number of positive culture, even if the difference was not statistically significant [50]. Lima et al. indicated that medications containing 2\% Chlorhexidine were able to eliminate biofilms of E. faecalis at 1 and 3 days of maturation [51]. Other in vitro works using a broth dilution test have shown that $2.0 \%$ Chlorhexidine and $5.25 \% \mathrm{NaOCl}$ have similar antimicrobial performance against all tested microorganisms [52 - 54] using the agar diffusion method. Ercan et al. [55] evaluated in vivo the antibacterial activity of 2\% Chlorhexidine as irrigating solution in infected teeth compared to $\mathrm{NaOCl}$. Counting of CFU (Colony Forming Units) in samples obtained from the root canals before and after chemo-mechanical preparation showed that both Chlorhexidine gluconate and sodium hypoclorite were significantly effective to reduce the endodontic pathogens in teeth with periapical pathologies. Chlorhexidine was significantly less effective against $E$. faecalis biofilm compared to $6 \%$ sodium hypochlorite [33].

Endo et al. in a clinical study on secondarily infected root canals with post-treatment apical periodontitis, used $2 \%$ Chlorhexidine gel for root canal irrigation [56]. They found that chemo-mechanical preparation was more effective in reducing bacteria (99.61\%) than endotoxin (60.6\%). If Chlorhexidine is extruded through the apex, it does not induce pain to the patients. However, the structure of the Chlorhexidine molecules poses a systemic risk because it is likely to decompose into reactive byproducts, such as para-chloroaniline [57].

\section{MTAD}

The poor effectiveness of sodium hypochlorite ascribed to its inactivation by dentin and collagen, has induced many researchers to analyze antibiotic-based irrigants as an alternative because of their higher penetrating power. On this basis, a new root canal irrigant known as MTAD, comprising a tetracycline isomer (doxycycline) $150 \mathrm{mg} / 5 \mathrm{ml}$, citric acid, and a detergent (Tween 80), has been introduced for use as a final irrigation solution. This is reported to eliminate microorganisms that are resistant to conventional root canal irrigants [58].

The antimicrobial action is not due to the doxycycline alone, but it is the result of a synergistic effect among the various components [59]. Doxycycline is effective against clinical isolates of E. faecalis, whilst citric acid removes the smear layer and the surfactants may facilitate the penetration of the medicament. On the downside, numerous authors have showed that MTAD was unsuccessful in the disintegration and removal of E. faecalis biofilms [37, 60, 61].

\section{Phytotherapic Agents}

An increasing number of studies have examined the activity and possible applications of new and natural substances for root canal disinfection [62].

Phytotherapy has evolved as a science, and there has been growing interest in evaluating plant extracts with a potential therapeutic application in dentistry. Below are some of the more relevant substances that may offer a viable alternative to the leading irrigants in the field. 


\section{Uncaria tomentosa}

Commonly known as "cat's claw" because of the small curved spines on the stem at the leaf juncture, it offers an anti-inflammatory, antiviral, antibacterical, antioxidant, and immunomodulating action [63]. Its toxicity is low when used correctly, this being an important advantage of medicinal plant treatments over more conventional methods [64]. Herrera et al. have evaluated the antimicrobial activity of Uncaria tomentosa against E. Faecalis, S. Aureus and $C$. albicans [65]. 2\% Uncaria tomentosa gel and 2\% Chlorhexidine gel had similar antimicrobical activity against $S$. aureus, while Chlorhexidine is more effective against $E$. faecalis and C. albicans.

U. Tomentosa contains triterpens, vegetal steroids and glycoides, these compounds may be related to its antimicrobial activity [66, 67].

\section{Apple Vinegar}

The use of different chemical irrigants for smear layer removal during the root canal treatment has also been proposed, with EDTA, citric acid, maleic acid and apple vinegar offering the most interesting results. Apple vinegar has been indicated as an antiseptic agent due to its medicinal properties, with its use as an auxiliary solution in the chemomechanical preparation of root canals showing good results when compared to $\mathrm{NaOCl}$ and EDTA [68].

The efficacy of apple vinegar on the endodontic microbiota has been evaluated, showing a good bactericidal action against microorganism associated with endodontic irrigations, such as $S$. Aureus and E. Faecalis [69].

Schinus terebintifolius Raddi (aroeira-da-praia) and Syderoxylum obtusifolium Roem \& Schult (quixabeira)

Schinus terebintifolius Raddi extracts have been employed as an anti-inflammatory and antimicrobial agent, with studies having demonstrated that acute and subacute administrations of the substances do not produce toxic effects on Wistar rats. On the contrary, only a few researches have investigated the therapeutic potential of Syderoxylum obtusifolium Roem \& Schult, which has been used as an alternative medicine in the northeast of Brazil for the treatment of oral infections [70].

Tests conducted through the agar well diffusion method have compared the antimicrobial activities of Schinus terebintifolius Raddi and Syderoxylum obtusifolium Roem \& Schult hydroalcoholic extracts, with those of $2.5 \%$ sodium hypochlorite and of $0.12 \%$ Chlorhexidine (positive control) against Enterococcus faecalis. The antimicrobial activity of aroeira-da-praia and quixabeira hydroalcoholic extracts against Enterococcus faecalis (ATCC 29212) was evaluated at the concentrations of $100 \%, 50 \%, 25 \%, 12.5 \%$ and $6.25 \%$ and compared with other solutions containing $2.5 \% \mathrm{NaOCl}$ and $0.12 \%$ Chlorhexidine. Tests were performed on agar plates after 48 hours of incubation at $37^{\circ} \mathrm{C}$. All solutions tested demonstrated antimicrobial activity against Enterococcus faecalis [71].

\section{Propolis and Zingiber officinale}

Propolis presents anti-inflammatory and antimicrobial actions [72 - 74]. Duarte et al. showed its influence in the reduction of acid production by $S$. mutans in the dental biofilm, besides its inhibitory action over the F-ATPase activity of $S$. mutans [75].

Ferreira et al. evaluated the in vitro antimicrobial activity of propolis against anaerobic bacteria, such as Prevotella nigrescens, Fusobacterium nucleatum, and Enterococcus faecalis [76]. The microbiologic analysis did not reveal differences between groups irrigated with propolis and groups treated with other intracanal medicaments such as calcium hydroxide, camphorated para-monochlorophenol, and formocresol; these results are further confirmed by other authors.

For example Valera et al. evaluated the action of propolis and intracanal medications against Escherichia coli and endotoxin [77]. A biomechanical preparation with propolis extract was able to reduce the amount of endotoxins from the root canals, yet not completely inactivating them. The real mechanism of action of propolis appears to be rather complex and some authors attribute to flavonoids the higher antimicrobial activity [72, 73].

While observing the antimicrobial activity of ginger extracts on Gram-negative anaerobes Porphyromonas gingivalis, Porphyromonas endodontalis and Prevotella intermedia, it was discovered that [10]-gingerol and [12]gingerol from the ginger rhizome evidenced potent antibacterial activities in vitro against anaerobic bacteria associated with periodontitis of the human oral cavity [78]. Maekawa et al. have evaluated the effectiveness of glycole propolis and ginger extract, calcium hydroxide and Chlorhexidine alone and in combination as intermediate canal medication, on extracted teeth after contaminations with Candida albicans, Enterococcus faecalis and Escherichia coli [79]. While all 
medications were able to eliminate the microorganisms in the root canals and reduce their amount of endotoxins, calcium hydroxide proved more effective in neutralizing endotoxins and less effective against $C$. albicans and $E$. faecalis. Instead, the effect of Ginger extracts on E. faecalis during biomechanical instrumentation on extracted teeth, was statistically similar to $2.5 \% \mathrm{NaOCl}$ and $2 \%$ Chlorhexidine [80].

\section{Castor Oil Detergent (Ricinus communis)}

Castor oil detergent has shown antimicrobial activity and biocompatibility, non-toxic results and detergent properties which are important requirements for an irrigant solution [81]. Endodontic irrigation with castor oil extract is capable of removing debris, showing similar results to $1 \% \mathrm{NaOCl}$ [82]. Root canal irrigation with castor oil reduces the number of Escherichia coli [83] and E. faecalis [81] during biomechanical preparation.

\section{Essential Oils}

Essential oils obtained from plants which have been known and used for centuries (spices, medicinal and aromatic plants) are increasingly tested for their antibacterial and antifungal activity. The antimicrobial activity of essential oils is strictly connected to their chemical composition, which is influenced by numerous factors including (but not limited to) the provenance of the plant, the part of plant used, the stage of plant development, climatic and growth condition (temperature, soil, fertilizers, etc.) as well as distillation and storage conditions. The mechanism of essential oil action towards microorganisms is complex and the common opinion is that the antibacterial action depends on their hydrophilic or lipophilic character. Terpenoids are an example of lipid soluble agents which affect the function of membrane-catalyzed enzymes, for instance their action on respiratory pathways. Certain components of essential oils can act as uncouplers, which interfere with proton translocation over a membrane vesicle and subsequently interrupt ADP phosphorylation (primary energy metabolism). Specific terpenoids with functional groups, such as phenolic alcohols or aldehydes, also interfere with membrane-integrated or associated enzyme proteins, stopping their production or activity [84].

The mode of action of antimicrobial agents also depends on the type of microorganisms and is mainly related to their cell wall structure and the outer membrane arrangement. The susceptibility of a microorganism to essential oils depends, first of all, on the properties of the essential oil and the microorganism itself. Some general rules have been set, which enable us sometimes to predict the results of experiments. However, considering the specificity of both the microorganism and the essential oil, separate experiments for each system should be undertaken [85].

The antimicrobial property of essential oils from plants was used empirically for centuries, but only recently it has been studied scientifically. Dormans and Deans evaluated the antibacterial activity against 25 different genera of bacteria, all of which had a degree of sensitivity to essential oils tested [86]. Oils with higher activity were thyme, oregano and cloves.

Clove oil offers antibacterial and antifungal actions, and is used as an antiseptic in oral infections [87, 88]. The high levels of eugenol in clove essential oil are responsible for its strong antimicrobial activity, with its phenolic compound being able to denature protein and react with cell membranes' phospholipids changing their permeability and inhibiting Gram-negative and Gram-positive bacteria [89]. Clove essential oil can be considered as a potential antimicrobial agent for external use because it is not inactivated by dilution or affected by organic matter [90].

Another essential oil worthy of mention is Cupressus lusitanica Mill, which is commonly used to treat hemorrhoids, rheumatism, whooping cough and skin infections [91] and it is rich in $\alpha$-pinene and $\delta$-3-carene [92]. The MIC value of oil for E. faecalis (ATCC10541) ranged from $1.25(10 \% \mathrm{v} / \mathrm{v})$ compared to a $15.62 \mu \mathrm{g} / \mathrm{ml}$ of the reference compound (gentamicin); the lethal dose of this extract was evaluated at $6.33 \mathrm{~g} / \mathrm{Kg}$ bodyweight on male Wistar albino rats [93].

Also exhibiting satisfactory antifungal, antibacterial and antioxidant activities [94, 95], Myrtus communis is an evergreen small tree with a wide distribution in Iran and other tropical regions of the world. Nabavizadeh et al. have found that the Myrtus communis essential oil inhibited the growth of E. faecalis and S. aureus with a lower MIC compared to $\mathrm{NaOCl}$; the main constituents of Myrtus essential oil were 1,8-cineole, $\alpha$-pinene and linalool [96].

\section{RESULTS}

An ideal endodontic irrigant should possess some essential properties already covered by many authors, but to this date there is no such substance known to researchers. Some endodontic irrigants do show good antimicrobial activity, however they might result toxic; others dissolve the smear layer, but do not efficiently disinfect the root canal system. 
E. faecalis is considered the principal pathogen related to endodontic infections.

$\mathrm{NaOCl}$ is the main recommended irrigant by experts due to its antibacterial activity and dissolving capacity on pulp tissue, and presently the most efficient antibacterial agent for root canal disinfection. Numerous antimicrobial agents, like Chlorhexidine, have been proposed as alternatives for root canal disinfection. Chlorhexidine is relatively non-toxic but its efficacy is questionable, being that some authors reported a reduced activity against E. faecalis biofilm and endotoxins compared to $\mathrm{NaOCl}$.

The antimicrobial action of MTAD is due to its complex formulation but even so, it is not able to completely disintegrate and remove the E. faecalis biofilm.

It is often requested by patients that the irrigant be formulated with natural substances, since many prefer holistic medicine. Thus five plant extracts have been selected for further studies.

Uncaria tomentosa has proved less effective than Chlorhexidine against E. faecalis, but it does have antiinflammatory and immunomodulating properties.

Apple vinegar has shown good preliminary results in animal experiments regarding its smear-layer removal abilities.

Propolis and ginger extracts have demonstrated good activity as intracanal medicaments in ex vivo studies.

The research on the effects of essential oils on E. faecalis is still scarce, thus further studies on the subject should be conducted. In particular, pre-clinical studies would be necessary.

\section{CONCLUSION}

The purpose of endodontic treatment of teeth with pulpal necrosis and apical periodontitis is to eliminate microorganisms from the root canal system, dentinal tubules and the periapical region. $\mathrm{NaOCl}$ has continuously demonstrated stronger antimicrobial efficacy in the endodontic space than other irrigation solutions. The most important disadvantage of $\mathrm{NaOCl}$ is its strong toxicity to the periapical tissues when it extrudes through the apex. Many plant extracts have shown pharmaceutical potential against several microorganisms such as Enterococcus faecalis, but further studies have demonstrated their inefficacy when used in ex vivo studies.

The literature analyzed thus far, has focused its attention on plant derivatives that are capable of antibacterial activity against Enterococcus faecalis, without in vivo studies. We can therefore hypothesize that some of these phytotherapic substances could be a potential alternative to $\mathrm{NaOCl}$ for the biomechanical treatment of the endodontic space.

\section{CONFLICT OF INTEREST}

The authors confirm that this article content has no conflict of interest.

\section{ACKNOWLEDGEMENTS}

Declared none.

\section{REFERENCES}

[1] Nair PN. Pathogenesis of apical periodontitis and the causes of endodontic failures. Crit Rev Oral Biol Med 2004; 15(6): 348-81. [http://dx.doi.org/10.1177/154411130401500604] [PMID: 15574679]

[2] Krause TA, Liewehr FR, Hahn CL. The antimicrobial effect of MTAD, sodium hypochlorite, doxycycline, and citric acid on Enterococcus faecalis. J Endod 2007; 33(1): 28-30.

[http://dx.doi.org/10.1016/j.joen.2006.08.011] [PMID: 17185124]

[3] Spratt DA, Pratten J, Wilson M, Gulabivala K. An in vitro evaluation of the antimicrobial efficacy of irrigants on biofilms of root canal isolates. Int Endod J 2001; 34(4): 300-7.

[http://dx.doi.org/10.1046/j.1365-2591.2001.00392.x] [PMID: 11482142]

[4] Dalton BC, Orstavik D, Phillips C, Pettiette M, Trope M. Bacterial reduction with nickel-titanium rotary instrumentation. J Endod 1998; 24(11): 763-7. [http://dx.doi.org/10.1016/S0099-2399(98)80170-2] [PMID: 9855830]

[5] Pataky L, Iványi I, Grigár A, Fazekas A. Antimicrobial efficacy of various root canal preparation techniques: an in vitro comparative study. J Endod 2002; 28(8): 603-5.

[http://dx.doi.org/10.1097/00004770-200208000-00010] [PMID: 12184424] 
[6] Chávez de Paz LE, Bergenholtz G, Svensäter G. The effects of antimicrobials on endodontic biofilm bacteria. J Endod 2010; 36(1): 70-7. [http://dx.doi.org/10.1016/j.joen.2009.09.017] [PMID: 20003938]

[7] Blome B, Braun A, Sobarzo V, Jepsen S. Molecular identification and quantification of bacteria from endodontic infections using real-time polymerase chain reaction. Oral Microbiol Immunol 2008; 23(5): 384-90. [http://dx.doi.org/10.1111/j.1399-302X.2008.00440.x] [PMID: 18793361]

[8] Valera MC, Silva KC, Maekawa LE, et al. Antimicrobial activity of sodium hypochlorite associated with intracanal medication for Candida albicans and Enterococcus faecalis inoculated in root canals. J Appl Oral Sci 2009; 17(6): 555-9. [http://dx.doi.org/10.1590/S1678-77572009000600003] [PMID: 20027425]

[9] Nair PN, Sjögren U, Krey G, Kahnberg KE, Sundqvist G. Intraradicular bacteria and fungi in root-filled, asymptomatic human teeth with therapy-resistant periapical lesions: a long-term light and electron microscopic follow-up study. J Endod 1990; 16(12): 580-8. [http://dx.doi.org/10.1016/S0099-2399(07)80201-9] [PMID: 2094761]

[10] Waltimo TM, Sen BH, Meurman JH, Ørstavik D, Haapasalo MP. Yeasts in apical periodontitis. Crit Rev Oral Biol Med 2003 ; $14(2)$ : 128-37. [http://dx.doi.org/10.1177/154411130301400206] [PMID: 12764075]

[11] Stuart CH, Schwartz SA, Beeson TJ, Owatz CB. Enterococcus faecalis: its role in root canal treatment failure and current concepts in retreatment. J Endod 2006; 32(2): 93-8.

[http://dx.doi.org/10.1016/j.joen.2005.10.049] [PMID: 16427453]

[12] Chávez De Paz LE, Dahlén G, Molander A, Möller A, Bergenholtz G. Bacteria recovered from teeth with apical periodontitis after antimicrobial endodontic treatment. Int Endod J 2003; 36(7): 500-8. [http://dx.doi.org/10.1046/j.1365-2591.2003.00686.x] [PMID: 12823706]

[13] Jaju S, Jaju PP. Newer root canal irrigants in horizon: a review. Int J Dent 2011; 2011: 351-9. [http://dx.doi.org/10.1155/2011/851359]

[14] Molander A, Reit C, Dahlén G, Kvist T. Microbiological status of root-filled teeth with apical periodontitis. Int Endod J 1998; 31 (1): 1-7. [http://dx.doi.org/10.1046/j.1365-2591.1998.t01-1-00111.x] [PMID: 9823122]

[15] Sedgley CM, Lennan SL, Appelbe OK. Survival of Enterococcus faecalis in root canals ex vivo. Int Endod J 2005; 38(10): 735-42. [http://dx.doi.org/10.1111/j.1365-2591.2005.01009.x] [PMID: 16164688]

[16] Ørstavik D, Haapasalo M. Disinfection by endodontic irrigants and dressings of experimentally infected dentinal tubules. Endod Dent Traumatol 1990; 6(4): 142-9. [http://dx.doi.org/10.1111/j.1600-9657.1990.tb00409.x] [PMID: 2133305]

[17] Distel JW, Hatton JF, Gillespie MJ. Biofilm formation in medicated root canals. J Endod 2002; 28(10): 689-93. [http://dx.doi.org/10.1097/00004770-200210000-00003] [PMID: 12398165]

[18] Zehnder M. Root canal irrigants. J Endod 2006; 32(5): 389-98. [http://dx.doi.org/10.1016/j.joen.2005.09.014] [PMID: 16631834]

[19] Kishen A, Sum CP, Mathew S, Lim CT. Influence of irrigation regimens on the adherence of Enterococcus faecalis to root canal dentin. J Endod 2008; 34(7): 850-4. [http://dx.doi.org/10.1016/j.joen.2008.04.006] [PMID: 18570994]

[20] Pinheiro ET, Gomes BP, Ferraz CC, Sousa EL, Teixeira FB, Souza-Filho FJ. Microorganisms from canals of root-filled teeth with periapical lesions. Int Endod J 2003; 36(1): 1-11. [http://dx.doi.org/10.1046/j.1365-2591.2003.00603.x] [PMID: 12656508]

[21] Sundqvist G, Figdor D, Persson S, Sjögren U. Microbiologic analysis of teeth with failed endodontic treatment and the outcome of conservative re-treatment. Oral Surg Oral Med Oral Pathol Oral Radiol Endod 1998; 85(1): 86-93. [http://dx.doi.org/10.1016/S1079-2104(98)90404-8] [PMID: 9474621]

[22] Kreft B, Marre R, Schramm U, Wirth R. Aggregation substance of Enterococcus faecalis mediates adhesion to cultured renal tubular cells. Infect Immun 1992; 60(1): 25-30. [PMID: 1729187]

[23] Kayaoglu G, Ørstavik D. Virulence factors of Enterococcus faecalis: relationship to endodontic disease. Crit Rev Oral Biol Med 2004; 15(5): 308-20. [http://dx.doi.org/10.1177/154411130401500506] [PMID: 15470268]

[24] Akpata ES, Blechman H. Bacterial invasion of pulpal dentin wall in vitro. J Dent Res 1982; 61(2): $435-8$. [http://dx.doi.org/10.1177/00220345820610021401] [PMID: 6120188]

[25] Haapasalo M, Orstavik D. In vitro infection and disinfection of dentinal tubules. J Dent Res 1987; 66(8): $1375-9$. [http://dx.doi.org/10.1177/00220345870660081801] [PMID: 3114347]

[26] Love RM. Enterococcus faecalisa mechanism for its role in endodontic failure. Int Endod J 2001; 34(5): $399-405$. [http://dx.doi.org/10.1046/j.1365-2591.2001.00437.x] [PMID: 11482724]

[27] Fabricius L, Dahlén G, Holm SE, Möller AJ. Influence of combinations of oral bacteria on periapical tissues of monkeys. Scand J Dent Res 1982; 90(3): 200-6.

[PMID: 7051261] 
[28] Sobrinho AP, Barros MH, Nicoli JR, et al. Experimental root canal infections in conventional and germ-free mice. J Endod 1998; 24(6): 405-8. [http://dx.doi.org/10.1016/S0099-2399(98)80021-6] [PMID: 9693583]

[29] Navarro-Escobar E, González-Rodríguez MP, Ferrer-Luque CM. Cytotoxic effects of two acid solutions and 2.5\% sodium hypochlorite used in endodontic therapy. Med Oral Patol Oral Cir Bucal 2010; 15(1): e90-4. [PMID: 19680178]

[30] Berutti E, Marini R, Angeretti A. Penetration ability of different irrigants into dentinal tubules. J Endod 1997; 23(12): 725-7. [http://dx.doi.org/10.1016/S0099-2399(97)80342-1] [PMID: 9487845]

[31] Kandaswamy D, Venkateshbabu N. Root canal irrigants. J Conserv Dent 2010; 13(4): $256-64$ [http://dx.doi.org/10.4103/0972-0707.73378] [PMID: 21217955]

[32] Berber VB, Gomes BP, Sena NT, et al. Efficacy of various concentrations of NaOCl and instrumentation techniques in reducing Enterococcus faecalis within root canals and dentinal tubules. Int Endod J 2006; 39(1): 10-7. [http://dx.doi.org/10.1111/j.1365-2591.2005.01038.x] [PMID: 16409323]

[33] Williamson AE, Cardon JW, Drake DR. Antimicrobial susceptibility of monoculture biofilms of a clinical isolate of Enterococcus faecalis. J Endod 2009; 35(1): 95-7.

[http://dx.doi.org/10.1016/j.joen.2008.09.004] [PMID: 19084133]

[34] Sirtes G, Waltimo T, Schaetzle M, Zehnder M. The effects of temperature on sodium hypochlorite short-term stability, pulp dissolution capacity, and antimicrobial efficacy. J Endod 2005; 31(9): 669-71. [http://dx.doi.org/10.1097/01.don.0000153846.62144.d2] [PMID: 16123703]

[35] Carson KR, Goodell GG, McClanahan SB. Comparison of the antimicrobial activity of six irrigants on primary endodontic pathogens. J Endod 2005; 31(6): 471-3. [http://dx.doi.org/10.1097/01.don.0000148868.72833.62] [PMID: 15917691]

[36] Siqueira JF Jr, Rôças IN, Favieri A, Lima KC. Chemomechanical reduction of the bacterial population in the root canal after instrumentation and irrigation with $1 \%, 2.5 \%$, and 5.25\% sodium hypochlorite. J Endod 2000; 26(6): 331-4. [http://dx.doi.org/10.1097/00004770-200006000-00006] [PMID: 11199749]

[37] Giardino L, Ambu E, Savoldi E, Rimondini R, Cassanelli C, Debbia EA. Comparative evaluation of antimicrobial efficacy of sodium hypochlorite, MTAD, and Tetraclean against Enterococcus faecalis biofilm. J Endod 2007; 33(7): 852-5. [http://dx.doi.org/10.1016/j.joen.2007.02.012] [PMID: 17804328]

[38] Liu H, Wei X, Ling J, Wang W, Huang X. Biofilm formation capability of Enterococcus faecalis cells in starvation phase and its susceptibility to sodium hypochlorite. J Endod 2010; 36(4): 630-5. [http://dx.doi.org/10.1016/j.joen.2009.11.016] [PMID: 20307735]

[39] Soares JA, Roque de Carvalho MA, Cunha Santos SM, et al. Effectiveness of chemomechanical preparation with alternating use of sodium hypochlorite and EDTA in eliminating intracanal Enterococcus faecalis biofilm. J Endod 2010; 36(5): 894-8. [http://dx.doi.org/10.1016/j.joen.2010.01.002] [PMID: 20416441]

[40] Kuruvilla JR, Kamath MP. Antimicrobial activity of $2.5 \%$ sodium hypochlorite and $0.2 \%$ chlorhexidine gluconate separately and combined, as endodontic irrigants. J Endod 1998; 24(7): 472-6. [http://dx.doi.org/10.1016/S0099-2399(98)80049-6] [PMID: 9693573]

[41] Gül S, Savsar A, Tayfa Z. Cytotoxic and genotoxic effects of sodium hypochlorite on human peripheral lymphocytes in vitro. Cytotechnology 2009; 59(2): 113-9.

[http://dx.doi.org/10.1007/s10616-009-9201-4] [PMID: 19484372]

[42] Kaufman AY, Keila S. Hypersensitivity to sodium hypochlorite. J Endod 1989; 15(5): 224-6. [http://dx.doi.org/10.1016/S0099-2399(89)80241-9] [PMID: 2607295]

[43] Calişkan MK, Türkün M, Alper S. Allergy to sodium hypochlorite during root canal therapy: a case report. Int Endod J 1994 ; $27(3)$ : 163-7. [http://dx.doi.org/10.1111/j.1365-2591.1994.tb00247.x] [PMID: 7995650]

[44] Serper A, Ozbek M, Calt S. Accidental sodium hypochlorite-induced skin injury during endodontic treatment. J Endod 2004; 30(3): 180-1. [http://dx.doi.org/10.1097/00004770-200403000-00013] [PMID: 15055439]

[45] Marending M, Paqué F, Fischer J, Zehnder M. Impact of irrigant sequence on mechanical properties of human root dentin. J Endod 2007; 33(11): 1325-8.

[http://dx.doi.org/10.1016/j.joen.2007.08.005] [PMID: 17963956]

[46] Soares CJ, Santana FR, Silva NR, Preira JC, Pereira CA. Influence of the endodontic treatment on mechanical properties of root dentin. J Endod 2007; 33(5): 603-6. [http://dx.doi.org/10.1016/j.joen.2007.01.016] [PMID: 17437882]

[47] Chivatxaranukul P, Dashper SG, Messer HH. Dentinal tubule invasion and adherence by Enterococcus faecalis. Int Endod J 2008; 41(10): $873-82$. [http://dx.doi.org/10.1111/j.1365-2591.2008.01445.x] [PMID: 18822013]

[48] Gomes BP, Vianna ME, Zaia AA, Almeida JF, Souza-Filho FJ, Ferraz CC. Chlorhexidine in endodontics. Braz Dent J 2013; $24(2)$ : 89-102. [http://dx.doi.org/10.1590/0103-6440201302188] [PMID: 23780357] 
[49] Delany GM, Patterson SS, Miller CH, Newton CW. The effect of chlorhexidine gluconate irrigation on the root canal flora of freshly extracted necrotic teeth. Oral Surg Oral Med Oral Pathol 1982; 53(5): 518-23. [http://dx.doi.org/10.1016/0030-4220(82)90469-8] [PMID: 6954427]

[50] Jeansonne MJ, White RR. A comparison of $2.0 \%$ chlorhexidine gluconate and $5.25 \%$ sodium hypochlorite as antimicrobial endodontic irrigants. J Endod 1994; 20(6): 276-8. [http://dx.doi.org/10.1016/S0099-2399(06)80815-0] [PMID: 7931023]

[51] Lima KC, Fava LR, Siqueira JF Jr. Susceptibilities of Enterococcus faecalis biofilms to some antimicrobial medications. J Endod 2001; 27(10): 616-9.

[http://dx.doi.org/10.1097/00004770-200110000-00004] [PMID: 11592490]

[52] Gomes BP, Ferraz CC, Vianna ME, Berber VB, Teixeira FB, Souza-Filho FJ. In vitro antimicrobial activity of several concentrations of sodium hypochlorite and chlorhexidine gluconate in the elimination of Enterococcus faecalis. Int Endod J 2001; 34(6): 424-8. [http://dx.doi.org/10.1046/j.1365-2591.2001.00410.x] [PMID: 11556507]

[53] Vianna ME, Gomes BP, Berber VB, Zaia AA, Ferraz CC, de Souza-Filho FJ. In vitro evaluation of the antimicrobial activity of chlorhexidine and sodium hypochlorite. Oral Surg Oral Med Oral Pathol Oral Radiol Endod 2004; 97(1): 79-84. [http://dx.doi.org/10.1016/S1079-2104(03)00360-3] [PMID: 14716261]

[54] Gomes BP, Vianna ME, Matsumoto CU, et al. Disinfection of gutta-percha cones with chlorhexidine and sodium hypochlorite. Oral Surg Oral Med Oral Pathol Oral Radiol Endod 2005; 100(4): 512-7. [http://dx.doi.org/10.1016/j.tripleo.2004.10.002] [PMID: 16182174]

[55] Ercan E, Ozekinci T, Atakul F, Gül K. Antibacterial activity of 2\% chlorhexidine gluconate and 5.25\% sodium hypochlorite in infected root canal: in vivo study. J Endod 2004; 30(2): 84-7. [http://dx.doi.org/10.1097/00004770-200402000-00005] [PMID: 14977302]

[56] Endo MS, Martinho FC, Zaia AA, Ferraz CC, Almeida JF, Gomes BP. Quantification of cultivable bacteria and endotoxin in post-treatment apical periodontitis before and after chemo-mechanical preparation. Eur J Clin Microbiol Infect Dis 2012; 31(10): $2575-83$. [http://dx.doi.org/10.1007/s10096-012-1598-6] [PMID: 22565224]

[57] Basrani BR, Manek S, Sodhi RN, Fillery E, Manzur A. Interaction between sodium hypochlorite and chlorhexidine gluconate. J Endod 2007; 33(8): 966-9. [http://dx.doi.org/10.1016/j.joen.2007.04.001] [PMID: 17878084]

[58] Zhang W, Torabinejad M, Li Y. Evaluation of cytotoxicity of MTAD using the MTT-tetrazolium method. J Endod 2003; $29(10)$ : 654-7. [http://dx.doi.org/10.1097/00004770-200310000-00010] [PMID: 14606789]

[59] Neglia R, Ardizzoni A, Giardino L, et al. Comparative in vitro and ex vivo studies on the bactericidal activity of Tetraclean, a new generation endodontic irrigant, and sodium hypochlorite. New Microbiol 2008; 31(1): 57-65. [PMID: 18437842]

[60] Dunavant TR, Regan JD, Glickman GN, Solomon ES, Honeyman AL. Comparative evaluation of endodontic irrigants against Enterococcus faecalis biofilms. J Endod 2006; 32(6): 527-31. [http://dx.doi.org/10.1016/j.joen.2005.09.001] [PMID: 16728243]

[61] Prabhakar J, Senthilkumar M, Priya MS, Mahalakshmi K, Sehgal PK, Sukumaran VG. Evaluation of antimicrobial efficacy of herbal alternatives (Triphala and green tea polyphenols), MTAD, and 5\% sodium hypochlorite against Enterococcus faecalis biofilm formed on tooth substrate: an in vitro study. J Endod 2010; 36(1): 83-6. [http://dx.doi.org/10.1016/j.joen.2009.09.040] [PMID: 20003940]

[62] Murray PE, Farber RM, Namerow KN, Kuttler S, Garcia-Godoy F. Evaluation of Morinda citrifolia as an endodontic irrigant. J Endod 2008; 34(1): 66-70.

[http://dx.doi.org/10.1016/j.joen.2007.09.016] [PMID: 18155496]

[63] Heitzman ME, Neto CC, Winiarz E, Vaisberg AJ, Hammond GB. Ethnobotany, phytochemistry and pharmacology of Uncaria (Rubiaceae). Phytochemistry 2005; 66(1): 5-29. [http://dx.doi.org/10.1016/j.phytochem.2004.10.022] [PMID: 15649507]

[64] Santa Maria A, Lopez A, Diaz MM, et al. Evaluation of the toxicity of Uncaria tomentosa by bioassays in vitro. J Ethnopharmacol 1997; 57(3): 183-7.

[http://dx.doi.org/10.1016/S0378-8741(97)00067-6] [PMID: 9292411]

[65] Herrera DR, Tay LY, Rezende EC, Kozlowski VA Jr, Santos EB. In vitro antimicrobial activity of phytotherapic Uncaria tomentosa against endodontic pathogens. J Oral Sci 2010; 52(3): 473-6.

[http://dx.doi.org/10.2334/josnusd.52.473] [PMID: 20881342]

[66] Aquino R, De Feo V, De Simone F, Pizza C, Cirino G. Plant metabolites. New compounds and anti-inflammatory activity of Uncaria tomentosa. j Nat Prod 1991; 54(2): 453-9. [http://dx.doi.org/10.1021/np50074a016]

[67] García R, Cayunao C, Bocic R, et al. Antimicrobial activity of isopteropodine. Z Naturforsch BJ Chem Sci 2005; 60(5-6): 385-8. [http://dx.doi.org/10.1515/znc-2005-5-603] [PMID: 16042336]

[68] Candeiro GT, Matos IB, Costa CF, Fonteles CS, Vale MS. A comparative scanning electron microscopy evaluation of smear layer removal 
with apple vinegar and sodium hypochlorite associated with EDTA. J Appl Oral Sci 2011; 19(6): 639-43.

[http://dx.doi.org/10.1590/S1678-77572011000600016] [PMID: 22231000]

[69] Estrela C, Holland R, Bernabé PF, de Souza V, Estrela CR. Antimicrobial potential of medicaments used in healing process in dogs teeth with apical periodontitis. Braz Dent J 2004; 15(3): 181-5. [http://dx.doi.org/10.1590/S0103-64402004000300003] [PMID: 15798819]

[70] Santos EB, Dantas GS, Santos HB, Diniz MF, Sampaio FC. Etnobotanical studies of medicinal plants for oral conditions in the municipality of João Pessoa, Brazil. (acaio n.d.). Bras Farmacogn 2009; 19: 321-4. [http://dx.doi.org/10.1590/S0102-695X2009000200024]

[71] Costa EM, Evangelista AP, Medeiros AC, Dametto FR, Carvalho RA. In vitro evaluation of the root canal cleaning ability of plant extracts and their antimicrobial action. Braz Oral Res 2012; 26(3): 215-21. [http://dx.doi.org/10.1590/S1806-83242012000300006] [PMID: 22641440]

[72] Grange JM, Davey RW. Antibacterial properties of propolis (bee glue). J R Soc Med 1990; 83(3): 159-60. [PMID: 2182860]

[73] Koo H, Gomes BP, Rosalen PL, Ambrosano GM, Park YK, Cury JA. In vitro antimicrobial activity of propolis and Arnica montana against oral pathogens. Arch Oral Biol 2000; 45(2): 141-8. [http://dx.doi.org/10.1016/S0003-9969(99)00117-X] [PMID: 10716618]

[74] Oncag O, Cogulu D, Uzel A, Sorkun K. Efficacy of propolis as an intracanal medicament against Enterococcus faecalis. Gen Dent 2006; 54(5): 319-22. [PMID: 17004565]

[75] Duarte S, Gregoire S, Singh AP, et al. Inhibitory effects of cranberry polyphenols on formation and acidogenicity of Streptococcus mutans biofilms. FEMS Microbiol Lett 2006; 257(1): 50-6. [http://dx.doi.org/10.1111/j.1574-6968.2006.00147.x] [PMID: 16553831]

[76] Ferreira FB, Torres SA, Rosa OP, et al. Antimicrobial effect of propolis and other substances against selected endodontic pathogens. Oral Surg Oral Med Oral Pathol Oral Radiol Endod 2007; 104(5): 709-16. [http://dx.doi.org/10.1016/j.tripleo.2007.05.019] [PMID: 17964476]

[77] Valera MC, da Rosa JA, Maekawa LE, et al. Action of propolis and medications against Escherichia coli and endotoxin in root canals. Oral Surg Oral Med Oral Pathol Oral Radiol Endod 2010; 110(4): e70-4. [http://dx.doi.org/10.1016/j.tripleo.2010.01.029] [PMID: 20868987]

[78] Park M, Bae J, Lee DS. Antibacterial activity of [10]-gingerol and [12]-gingerol isolated from ginger rhizome against periodontal bacteria. Phytother Res 2008; 22(11): 1446-9.

[http://dx.doi.org/10.1002/ptr.2473] [PMID: 18814211]

[79] Maekawa LE, Valera MC, Oliveira LD, Carvalho CA, Camargo CH, Jorge AO. Effect of Zingiber officinale and propolis on microorganisms and endotoxins in root canals. J Appl Oral Sci 2013; 21(1): 25-31. [http://dx.doi.org/10.1590/1678-7757201302129] [PMID: 23559108]

[80] Valera MC, Maekawa LE, de Oliveira LD, Jorge AO, Shygei É, Carvalho CA. In vitro antimicrobial activity of auxiliary chemical substances and natural extracts on Candida albicans and Enterococcus faecalis in root canals. J Appl Oral Sci 2013; 21(2): 118-23. [http://dx.doi.org/10.1590/1678-7757201302135] [PMID: 23739849]

[81] Camargo SE, Rode SdeM, do Prado RF, Carvalho YR, Camargo CH. Subcutaneous tissue reaction to castor oil bean and calcium hydroxide in rats. J Appl Oral Sci 2010; 18(3): 273-8. [http://dx.doi.org/10.1590/S1678-77572010000300014] [PMID: 20857007]

[82] Meneghin MP, Nomelini SM, Sousa-Neto MD, Marchesan MA, França SC, dos Santos HS. Morphologic and morphometric analysis of the root canal apical third cleaning after biomechanical preparation using 3.3\% Ricinus communis detergent and $1 \% \mathrm{NaOCl}$ as irrigating solutions. J Appl Oral Sci 2006; 14(3): 178-82.

[http://dx.doi.org/10.1590/S1678-77572006000300006] [PMID: 19089069]

[83] Valera MC, Maekawa LE, Chung A, et al. Effectiveness of castor oil extract on Escherichia coli and its endotoxins in root canals. Gen Dent 2012; 60(4): e204-9. [PMID: 22782052]

[84] Knobloch K, Pauli A, Iberl B, Weigand H, Weis NJ. Antibacterial and antifungal properties of essential oil components. Essent Oil Res 1989; 1: $119-28$ [http://dx.doi.org/10.1080/10412905.1989.9697767]

[85] Kalemba D, Kunicka A. Antibacterial and antifungal properties of essential oils. Curr Med Chem 2003; $10(10)$ : 813-29. [http://dx.doi.org/10.2174/0929867033457719] [PMID: 12678685]

[86] Dorman HJ, Deans SG. Antimicrobial agents from plants: antibacterial activity of plant volatile oils. J Appl Microbiol 2000; 88(2): 308-16. [http://dx.doi.org/10.1046/j.1365-2672.2000.00969.x] [PMID: 10736000]

[87] Meeker HG, Linke HA. The antibacterial action of eugenol, thyme oil, and related essential oils used in dentistry. Compendium 1988; 9(1): 32-, 34-35, 38 passim. [PMID: 3278805] 
[88] Shapiro S, Meier A, Guggenheim B. The antimicrobial activity of essential oils and essential oil components towards oral bacteria. Oral Microbiol Immunol 1994; 9(4): 202-8. [http://dx.doi.org/10.1111/j.1399-302X.1994.tb00059.x] [PMID: 7478759]

[89] Chaieb K, Hajlaoui H, Zmantar T, et al. The chemical composition and biological activity of clove essential oil, Eugenia caryophyllata (Syzigium aromaticum L. Myrtaceae): a short review. Phytother Res 2007; 21(6): 501-6. [http://dx.doi.org/10.1002/ptr.2124] [PMID: 17380552]

[90] Nuñez L, Aquino MD. Microbicide activity of clove essential oil (Eugenia caryophyllata). Braz J Microbiol 2012; 43(4): 1255-60. [http://dx.doi.org/10.1590/S1517-83822012000400003] [PMID: 24031950]

[91] Duke J. Phytochemical Database (Phytochem DB) Beltsville Agricultural Research Center. Beltsville, MD: USDA-ARS NGRL, 2004.

[92] Adams RP, Zanoni TA, Lara A, Barrero AF, Cool LG. Comparison among Cupressus arizonica Greene, Cupressus benthamii Endl., Cupressus lindleyi Klotz. Ex Endl. And Cupressus lusitanica Mill. using leaf essential oils and DNA finger printing. J Essent Oil Res 1997; 9: 303-9. [http://dx.doi.org/10.1080/10412905.1997.10554249]

[93] Teke GN, Elisée KN, Roger KJ. Chemical composition, antimicrobial properties and toxicity evaluation of the essential oil of Cupressus lusitanica Mill. leaves from Cameroon. BMC Complement Altern Med 2013; 13: 130-8. [http://dx.doi.org/10.1186/1472-6882-13-130] [PMID: 23758765]

[94] Zomorodian K, Moein M, Goeini Lori Z, et al. Chemical composition and antimicrobial activities of the essential oil from Myrtus communis leaves. J Essential Oil Bear Plants 2013; 16: 76-84. [http://dx.doi.org/10.1080/0972060X.2013.764183]

[95] Rasooli I, Moosavi ML, Rezaei MB, Jaimand K. Susceptibility of microorganisms to Myrtus communis L. essential oil and its chemical composition. J Agric Sci Technol 2002; 4: 127-33.

[96] Nabavizadeh M, Abbaszadegan A, Gholami A, et al. Chemical constituent and antimicrobial effect of essential oil from Myrtus communis leaves on microorganisms involved in persistent endodontic infection compared to two common endodontic irrigants: An in vitro study. $\mathrm{J}$ Conserv Dent 2014; 17(5): 449-53.

[http://dx.doi.org/10.4103/0972-0707.139836] [PMID: 25298646]

C Borzini et al.; Licensee Bentham Open

This is an open access article licensed under the terms of the Creative Commons Attribution-Non-Commercial 4.0 International Public License (CC BY-NC 4.0) (https://creativecommons.org/licenses/by-nc/4.0/legalcode), which permits unrestricted, non-commercial use, distribution and reproduction in any medium, provided the work is properly cited. 